\title{
Bryostatin 1 causes attenuation of TPA-mediated tumor promotion in mouse skin
}

\author{
NING ZENG, YI XU, YIPING WU, TANG HONGBO and MIN WU \\ Department of Plastics and Aesthetic Surgery, Tongji Hospital, Tongji Medical College, \\ Huazhong University of Science and Technology, Wuhan, Hubei 430030, P.R. China
}

Received July 16, 2017; Accepted September 14, 2017

DOI: $10.3892 / \mathrm{mmr} .2017 .7993$

\begin{abstract}
The present study was designed to investigate the tumor inhibitory potential of bryostatin 1 in a 12-O-tetradecanoylphorbol-13-acetate (TPA)-induced mouse model of skin cancer. The radical inhibition potential of various doses of bryostatin 1 was investigated against 2,2-diphenyl-1-picrylhydrazyl (DPPH) bleach in vitro. The DPPH radical potential was observed compared with treatment with $5,10,15,20,25$ and $30 \mu \mathrm{M}$ doses of bryostatin 1 . In vivo, bryostatin 1 prevented the TPA-mediated increase in the level of $\mathrm{H}_{2} \mathrm{O}_{2}$ and myeloperoxidase in mouse epidermal tissue. Pretreatment of the mice with bryostatin $1(30 \mu \mathrm{M})$ followed by administration of TPA reduced the edema, as demonstrated via punched-out mouse ear tissue, to $7.2 \mathrm{mg}$, compared with $14 \mathrm{mg}$ in the TPA-treated group. Treatment with bryostatin 1 prior to TPA administration markedly prevented the inflammation of the skin by inhibiting hyperplasia in the epidermal layer and the aggregation of inflammatory cells. The results demonstrated that treatment of mice with bryostatin 1 at a $30 \mu \mathrm{M}$ dose prior to TPA administration significantly $(\mathrm{P}<0.005)$ inhibited the TPA-mediated increase in the level of COX-2. The activity of ornithine decarboxylase, increased by TPA, was additionally inhibited following pretreatment of the mice with bryostatin 1 . In the mice treated with bryostatin 1 at $30 \mu \mathrm{M}$ doses prior to the administration of TPA, the appearance of papillomas was $20 \%$, compared with $100 \%$ in the TPA group. Mice pretreated with bryostatin 1 at $30 \mu \mathrm{M}$ doses prior to TPA administration exhibited the appearance of 0.4 mean papillomas in each animal, compared with 5.2 in the TPA group. Therefore, the results of the present study demonstrated that bryostatin 1 inhibited the development and progression of tumors of skin in the mice, through the prevention of
\end{abstract}

Correspondence to: Dr Min Wu, Department of Plastics and Aesthetic Surgery, Tongji Hospital, Tongji Medical College, Huazhong University of Science and Technology, 1095 Jiefang Road, Wuhan, Hubei 430030, P.R. China

E-mail: madenareca@yahoo.com

Key words: radicals, papillomas, tumor, decarboxylase, myeloperoxidase inflammation-inducing processes and the quenching of radicals. Therefore, bryostatin 1 maybe considered to be adrug of importance in the treatment of skin tumor.

\section{Introduction}

Cancer is considered to be a process with multiple stages, and carcinogenicity depends on various factors, including the extent of oncogene activation and tumor suppressor gene mutations. In addition carcinogenicity is governed by the duration of carcinogenic factor exposure (1,2). Different physiochemical agents are known to induce carcinoma in the skin of animals. The sequence of processes involved includes damage to skin, tissue inflammation, formation of hyperplasia, appearance of papillomas and subsequent squamous cell cancer (3-5). The induction of papillomasmay be achieved by the administration of 12-O-tetradecanoylphorbol-13-acetate (TPA) to animal skin, which causes activation of oncogene transcribing factors, nuclear factor (NF) $\kappa \mathrm{B}$ and transcription factor AP-1 (AP-1) (6-8). Following the activation of NF- $\kappa$ B and AP-1, the rate of inflammatory processes, the initiation of cell proliferation and the production of papillomas are increased. Studies using models of skin carcinoma have led to the identification of various factors involved in the development and progression of skin tumor $(3,4)$. The use of mouse models of skin carcinoma led to the investigation of the role of inhibitors of tumor induction and malignant transformation in skin cancer (5). The results of previous study revealed that bioactive natural products isolated from plants may possess potent skin and epithelial cancer prevention potential (9). The progression of tumors is enhanced by cellular oxidative stress and inflammatory reactions, which indicates that the inhibition of these processes is of importance for the treatment of cancer (10). Natural products isolated from organisms of marine origin additionally serve as the source of a number of therapeutically potent compounds (11). An example of such a molecule, bryostatin 1 (Fig. 1) is isolated from the invertebrate Bugulaneritina, which is a member of the Ectoprocta phylum (11). Biological investigation has revealed that bryostatin 1 aids in the development of the immune system in addition to causing a promotion of hematopoietic differentiation and stimulation (12). A previous study demonstrated that treatment with bryostatin 1 resulted in the inhibition of phorbol ester-mediated induction of carcinoma growth and proliferation (13). In ovarian carcinoma, 
treatment with bryostatin 1 induced cell growth inhibition via the induction of apoptotic pathways $(11,14)$. In hepatic cancer, renal cancer, melanoma and leukaemia cell lines, exposure to bryostatin 1 inhibited viability and induced apoptosis (14-16). Studies involving rat models of carcinoma have revealed that there is direct association between the in vivo and in vitro anti-tumor potential of bryostatin 1 (16). The present study was designed to investigate the tumor inhibitory tendency of bryostatin 1 in a TPA-induced mouse model of skin cancer. The results demonstrated that bryostatin 1 inhibited the development and progression of tumors of skin in mice through the prevention of inflammation-inducing processes and the quenching of radicals.

\section{Materials and methods}

Chemicals and reagents. Bryostatin 1, benzo[ $\alpha]$ pyrene and TPA were supplied by Sigma-Aldrich (Merck KGaA, Darmstadt, Germany).

Animals. A total of 48 female 7-week old BALB/c nude mice (12-20 g) were obtained from the Animal Experiment Center of Beijing, China. The animals were housed in an animal facility center under conditions free of pathogens with 12 hourly light and dark cycle at $24^{\circ} \mathrm{C}$ with $30-70 \%$ humidity. All the mice were provided with access to food and water ad libitum. The animal experimental protocol was approved by the Animal Ethical Committee of the Tongji Medical College of Huazhong University of Sciences and Technology (Wuhan, China).

Treatment strategy. The day prior to the administration of bryostatin 1, the animals were shaved on the upper side of the body to remove all hair. The bryostatin $1(30 \mu \mathrm{M})$ was administered $10 \mathrm{~min}$ prior to the administration of TPA (7.2 mg). All animal protocols used in the present study were approved by the Committee of Experimental Animal Administration of the Second Military Medical University Laboratory (Shanghai, China).

Analysis of bryostatin 1 radical inhibition activity. For the determination of the radical inhibition activity of bryostatin 1, 2,2-diphenyl-1-picrylhydrazyl (DPPH) was used. From a 10 -mM stock solution of DPPH in methyl alcohol, $30 \mu \mathrm{l}$ was added to a tube containing various concentrations of bryostatin $1(5,10,15,20,25$ and $30 \mu \mathrm{M})$. Subsequently, $3 \mathrm{ml}$ methyl alcohol was added to the tube, which was allowed to stand for $30 \mathrm{~min}$. A total of $1 \mathrm{ml}$ distilled water and $3 \mathrm{ml}$ toluene was added to the tube, followed by centrifugation at 2,500 $\mathrm{x} \mathrm{g}$ for $15 \mathrm{~min}$ at room temperature. The absorbance of the tube was measured three times independently at a wavelength of $517 \mathrm{~nm}$.

In vivo radical inhibition activity of bryostatin 1 . The animals were shaved on the upper side of the body one day prior to the start of the experiment. The following day, $200 \mu \mathrm{l}$ 2-propanone was applied to the body surface, followed by the administration of $5 \mathrm{nmol}$ TPA two times with an intervening gap of $24 \mathrm{~h}$. The administration of $5 \mathrm{nmol}$ TPA was performed either subsequent to pretreatment with bryostatin 1 or without bryostatin 1 . Sacrifice of the mice was performed using

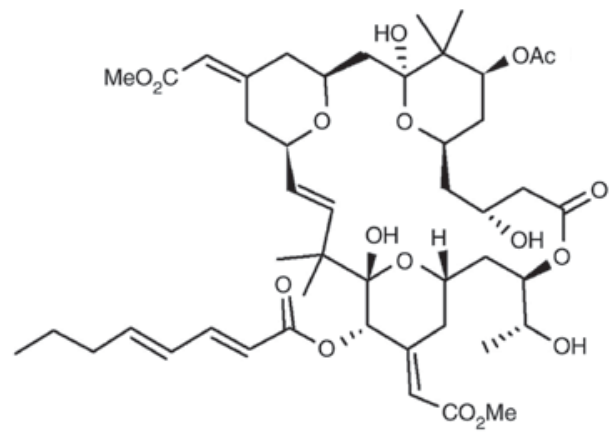

Figure 1. Chemical structure of bryostatin 1.

pentobarbital sodium (3\%), $2 \mathrm{~h}$ subsequent to the administration of the second TPA dose. The production of $\mathrm{H}_{2} \mathrm{O}_{2}$ induced by the administration of TPA, and its inhibition by bryostatin 1 , was subsequently determined. For this purpose, the mouse epidermal layers were extracted and treated with a buffer solution consisting of potassium hydrogen phosphate $(50 \mathrm{mM})$ and $\mathrm{NaN}_{3}(10 \mathrm{mM})$. The layers were subjected to homogenization using a Polytron homogenizer (Kinematica AG, Lucerne, Switzerland) followed by 15 min centrifugation at $(2,500 \mathrm{x} \mathrm{g})$ at $4^{\circ} \mathrm{C}$. A $0.5-\mathrm{ml}$ quantity of the collected supernatant was transferred to glass tubes, treated with phenol red $(0.2 \mathrm{mg} / \mathrm{ml})$ and subsequently subjected to incubation for $15 \mathrm{~min}$ at $37^{\circ} \mathrm{C}$. $1 \mathrm{~N}$ (normal) solution of sodium hydroxide (100 $\mu \mathrm{l})$ was added to the tubes, followed by absorbance measurements at $612 \mathrm{~nm}$. DMSO was used as control.

Skin myeloperoxidase (MPO) activity determination. Skin tissues, following extraction, were subjected to homogenization and treatment with a $0.5 \%$ solution of $\mathrm{C}_{16} \mathrm{H}_{33} \mathrm{~N}\left(\mathrm{CH}_{3}\right)_{3} \mathrm{Br}$ in $50 \mathrm{mMK}_{2} \mathrm{HPO}_{4}$ buffer using the Polytron homogenizer. Following homogenization, the samples were centrifuged for $20 \mathrm{~min}$ at $4^{\circ} \mathrm{C}$ at $2,000 \times \mathrm{g}$. A mixture of 4-aminoantipyrine (25 $\mathrm{mM})$, phenol $(2 \%)$ and hydrogen peroxide $(1.7 \mathrm{mM})$ was transferred to a glass tube. A total of $0.5 \mathrm{ml}$ tissue suspension was added to the tube and mixed thoroughly. For each tube, the absorbance was measured at a wavelength of $460 \mathrm{~nm}$. The activity of MPO in the skin tissue samples was expressed as units/g.

Determination of edema in mouse ear tissue. The mice in the untreated group were treated with TPA $(7.2 \mathrm{mg})$ solution in 2-propanone into the right ear (6 mice/group). In the treatment group, mice were given bryostatin 1 prior to the application of TPA solution in 2-propanone, whereas those in the normal control group received normal saline. Following $8 \mathrm{~h}$ of TPA administration, the mice were sacrificed using pentobarbital sodium $(3 \%)$ to extract an 8 -mm ear-punch for biopsies. The samples were weighed to record the increased weight in the untreated group.

Analysis of ornithine decarboxylase activity. The extracted skin samples from the mice were kept in water for $45 \mathrm{sec}$ at $60^{\circ} \mathrm{C}$ and subsequently transferred toice-cold water. The epidermal layer of the skin was treated with $50 \mathrm{mM} \mathrm{KH_{2 }} \mathrm{PO}_{4}$ buffer mixed with $2 \mathrm{mM}$ dithiothreitol and $0.1 \mathrm{mM}$ ethylene diamine tetra acetate. Homogenization of the epidermal layer 


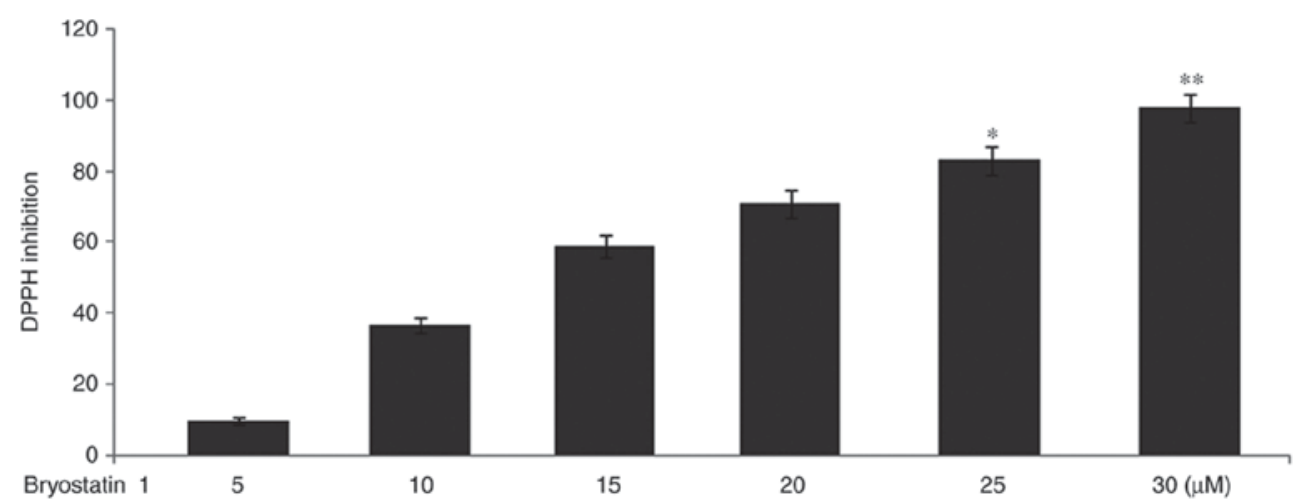

Figure 2. Bryostatin1 inhibits DPPH radical activity. Bryostatin1 at 5, 10, 15, 20, 25 and $30 \mu \mathrm{M}$ doses was added to DPPH radical solution followed by absorbance measurement at a wavelength of $517 \mathrm{~nm}$. The measurements were performed three times for each concentration, using dimethyl sulfoxide as the control. DPPH, 2,2-diphenyl-1-picrylhydrazyl. " $\mathrm{P}<0.05$ and ${ }^{* * *} \mathrm{P}<0.01$ vs. the control group.

was performed using the Polytron instrument, followed by centrifugation for $30 \mathrm{~min}$ at $12,000 \mathrm{xg}$ at $4^{\circ} \mathrm{C}$. The activity of ornithine decarboxylase in the supernatant was determined by monitoring the evolution of ${ }^{14} \mathrm{CO}_{2}$ using liquid scintillation counting (17).

Analysis of cyclooxygenase-2 (COX-2) activity. The epidermal layer was lysed using radioimmunoprecipitation assay buffer (Sigma-Aldrich, Merck KGaA) and a $\mathrm{DC}^{\mathrm{TM}}$ protein assay (Bio-Rad Laboratories, Inc., Hercules, CA, USA) was used for determination of the protein concentration in the samples. The extracted proteins ( $40 \mu \mathrm{g} /$ lane) were loaded and separated in $15 \%$ SDS-PAGE gel and then transferred to polyvinylidene fluoride membranes. The non-specific sites in the membranes were blocked for $15 \mathrm{~min}$ at room temperature via treatment with non-fat dried milk (5\%) in TBS with Tween-20 (TBS-T) buffer. Incubation with primary antibodies against COX-2 (1:500; cat. no. H-62; Santa Cruz Biotechnology Inc., Dallas, TX, USA) and $\alpha$-tubulin (1:500; cat. no. TU-02; Santa Cruz Biotechnology Inc.) for $1 \mathrm{~h}$ at $4^{\circ} \mathrm{C}$ was followed by washing with $4 \mathrm{X}$ TBS-T buffer. Membrane incubation was performed with horseradish peroxidase-conjugated anti-mouse immunoglobulin (1:10,000, cat. no. sc2005; Santa Cruz Biotechnology Inc.) for $1 \mathrm{~h}$ at $4^{\circ} \mathrm{C}$. Complexes formed by the interaction between proteins and antibodies were analyzed using an enhanced chemiluminescence detection system (GE Healthcare Bio-Sciences, Pittsburgh, PA, USA).

Histological analysis of skin. Following administration of TPA, either with or without pretreatment with bryostatin 1, the mice were sacrificed to extract skin samples. The samples were fixed in $10 \%$ neutral buffered formalin at $4^{\circ} \mathrm{C}$ overnight. Then, samples were embedded in paraffin and sectioned at a thickness of $4 \mu \mathrm{m}$. The samples were subjected to staining using hematoxylin and eosin for $10 \mathrm{~min}$ at $30^{\circ} \mathrm{C}$. Examination of the skin samples was performed using light microscope for the determination of epidermal thickness (indicators of hyperplasia) and infiltration of polymorpho nuclear (PMN) leukocytes (magnification, x100). For each section, six different randomly selected regions were observed.

Analysis of skin tumor formation. The mice were shaved on the upper side of the body and treated with 2-propanone the following day. For tumor initiation, benzo[ $\alpha]$ pyrene dissolved in 2-propanone was applied to the skin of the mice and the animals were kept under sterile conditions for 7 days. Subsequently, the mice were administered TPA, either without or with prior treatment with bryostatin 1. Following three months, the number of skin tumors in each mouse were counted with maximum size of $4 \mathrm{~mm}$.

Statistical analysis. Data are presented as the mean \pm standard error of the mean of three independent experiments. Statistical analysis was evaluated by one way analysis of variance followed by Bonferroni multiple-comparison test unless otherwise stated. All data analyses were performed using SPSS software package (version 17.0; SPSS, Inc., Chicago, IL, USA). $\mathrm{P}<0.05$ was considered to indicate a statistically significant difference.

\section{Results}

Bryostatinl inhibits DPPH radical activity. The radical inhibition potential of various doses of bryostatin 1 was investigated against DPPH bleach in vitro. With the increase in dosage of bryostatin1, a reduction was observed in the DPPH radical activity. The DPPH radical potential was reduced to 10,37 , $59,71,83$ and $98 \%$, respectively, at 5, 10, 15, 20, 25 and $30 \mu \mathrm{M}$ doses of bryostatin 1 (Fig. 2).

Pretreatment with Bryostatin1 prevents the TPA-mediated increase in the level of $\mathrm{H}_{2} \mathrm{O}_{2}$ and the activity of MPO. Administration of TPA to the mice at a concentration of $5 \mathrm{nmol}$ twice, with an intervening gap of $24 \mathrm{~h}$, led to a 3-fold increase in the $\mathrm{H}_{2} \mathrm{O}_{2}$ level in the epidermal layer compared with normal mice (Fig. 3). However, treatment of the mice with bryostatin1 prior to TPA administration prevented the increase in the level of $\mathrm{H}_{2} \mathrm{O}_{2}$ in the mouse epidermal layer. The $\mathrm{H}_{2} \mathrm{O}_{2}$ inhibition level was observed to be 3, 2.2, 1.8, 1.3, 1.2 and 1-fold higher in the mice following treatment with $5,10,15,20,25$ and $30 \mu \mathrm{M}$, respectively, bryostatin 1 . Administration of TPA to the mice at a concentration of $5 \mathrm{nmol}$ twice, with an intervening gap of $24 \mathrm{~h}$, led to a 30-fold increase in MPO activity compared with normal mice (Fig. 4). Treatment with bryostatin 1 prior to TPA administration at doses of $5,10,15,20,25$ and $30 \mu \mathrm{M}$, respectively, reduced the level of MPO activity in a dose dependent manner. 


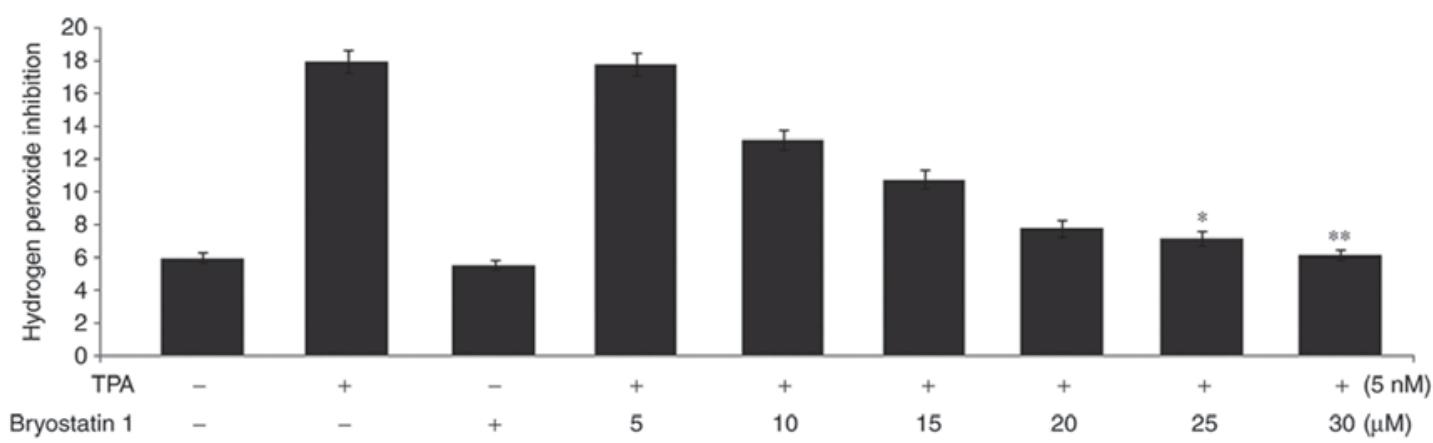

Figure 3. Bryostatin 1 inhibits the TPA-mediated production of hydrogen peroxide in the epidermal tissue of mice. Mice were administered with TPA either subsequent top retreatment with bryostatin 1 or without bryostatin 1 . The mice were sacrificed to extract the epidermal layer for analysis of the hydrogen peroxide level. ${ }^{*} \mathrm{P}<0.05$ and ${ }^{* *} \mathrm{P}<0.01$ vs. the control group. TPA, 12-O-tetradecanoylphorbol-13-acetate.

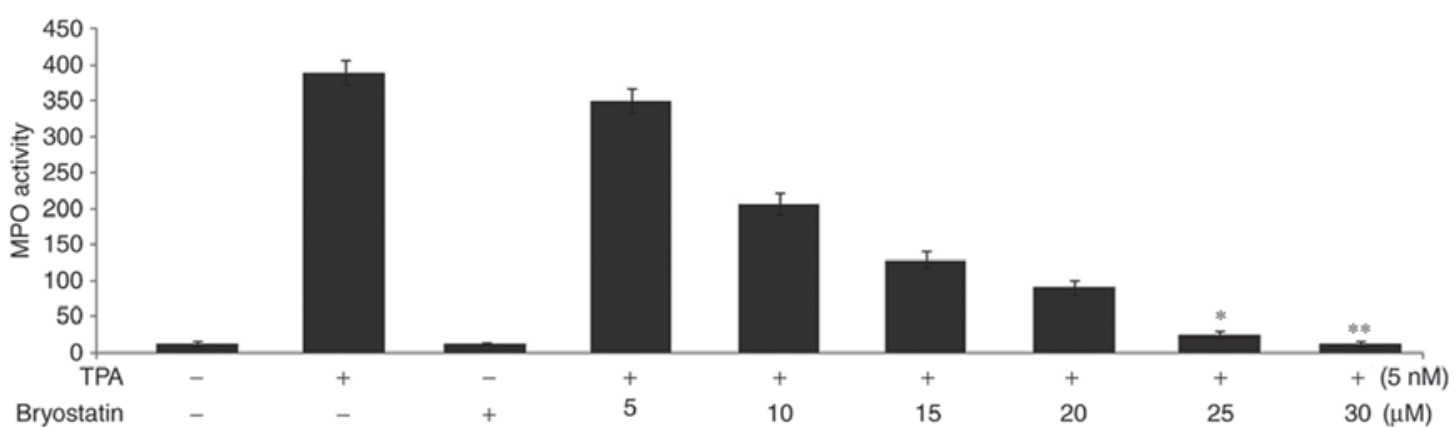

Figure 4. Bryostatin 1 inhibits the TPA-mediated increase in the activity of MPO in the skin of mice. Mice were administered with TPA, either subsequent to pretreatment with bryostatin 1 or without bryostatin 1 . The mice were sacrificed to extract the epidermal layer for analysis of the activity of MPO. "P<0.05 and ${ }^{* *} \mathrm{P}<0.01$ vs. the control group. MPO, myeloperoxidase; TPA, 12-O-tetradecanoylphorbol-13-acetate.

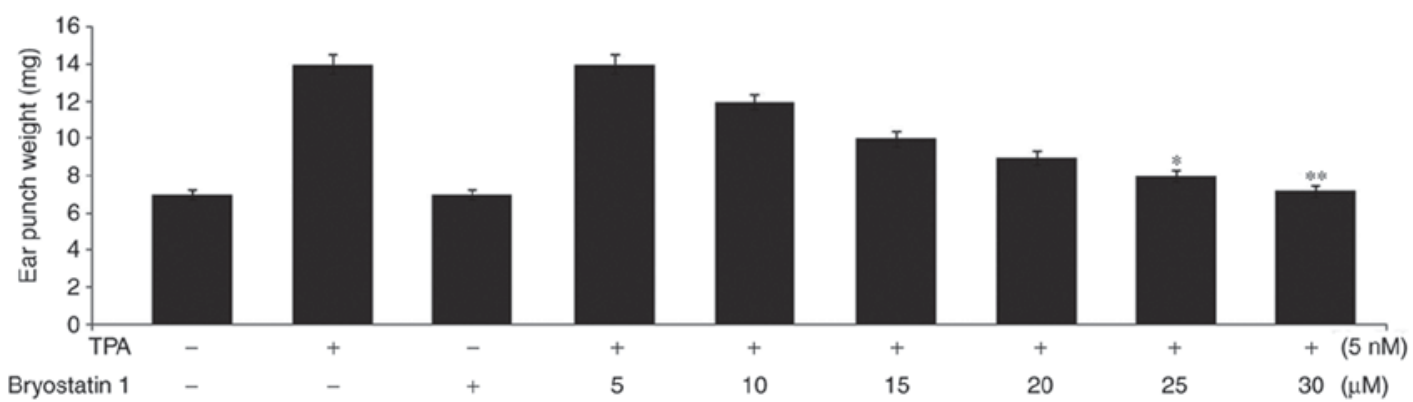

Figure 5. Bryostatin 1 inhibits ear edema in mice exposed to TPA. The ears of the mice were exposed to 2-propanone and administered with TPA, either untreated or following pretreatment with bryostatin 1 . Ear punches of animals were extracted following sacrifice to determine the weight. ${ }^{*} \mathrm{P}<0.05$ and ${ }^{* * *} \mathrm{P}<0.01$ vs. the control group. TPA, 12-O-tetradecanoylphorbol-13-acetate.

Bryostatin 1 prevents edema of the ear and skin inflammation caused by TPA administration in mice. In mice administered with $5 \mathrm{nmol}$ doses of TPA twice, with an intervening gap of $24 \mathrm{~h}$, edema formation was observed in the ear. The mean weight of the extracted edema masses from the mouse ears was recorded to be $14 \mathrm{mg}$. However, in mice pretreated with bryostatin 1 at doses of $5,10,15,20,25$ and $30 \mu \mathrm{M}$, the edema ear masses were recorded to be $14,12,10,9,8$ and $7.2 \mathrm{mg}$, respectively (Fig. 5). Administration of TPA to the mice for one week at a 5-nmoldose caused hyperplasia in the epidermal layer and aggregation of inflammatory cells leading to increased skin thickness. Treatment of the mice with bryostatin 1 prior to TPA administration markedly prevented inflammation of the skin by inhibiting hyperplasia in the epidermal layer and the aggregation of inflammatory cells (Fig. 6). At a $30-\mu \mathrm{M}$ concentration of bryostatin 1, inflammation of the skin in the mice was completely prevented.

Bryostatin 1 inhibits the TPA-mediated increased level of $C O X-2$. The mice administered with TPA exhibited marked increased levels of the protein COX-2 compared with the normal group. However, treatment of the mice with bryostatin 1 prior to TPA administration at a dosage of $30 \mu \mathrm{M}$ inhibited the TPA-mediated increase in the level of COX-2 (Fig. 7).

Bryostatin 1 inhibits the TPA-mediated increased activity of ornithine decarboxylase. The activity of ornithine decarboxylase was increased markedly in TPA-administered 


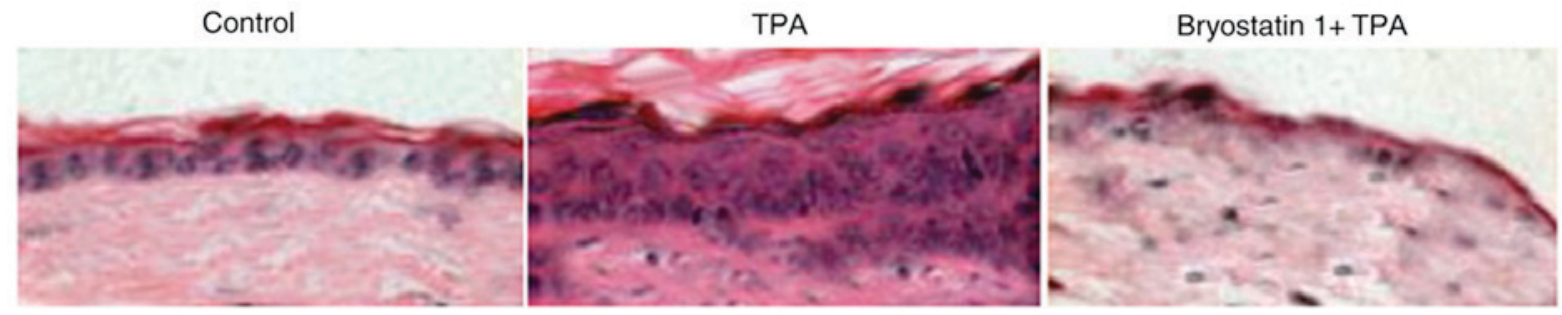

Figure 6. Treatment with bryostatin 1 prevents the TPA-mediated increase in skin thickness in mice. Following the application of 2-propanone, mice were administered TPA, either untreated or subsequent to pretreatment with bryostatin 1. Mouse skin was removed following sacrifice to determine the TPA-mediated increase in thickness histologically (magnification, x100). TPA, 12-O-tetradecanoylphorbol-13-acetate.

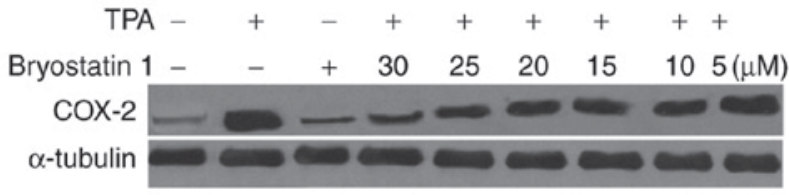

Figure 7. Bryostatin1 inhibits the TPA-mediated increase in the expression of COX-2 in the mouse epidermal layer. The mice were administered TPA with or without prior treatment withbryostatin1 at $30 \mu \mathrm{M}$. Following $8 \mathrm{~h}$ of TPA administration, the mouse epidermal layers were isolated subsequent to sacrificing the animals. The level of COX-2 was analyzed using western blotting. TPA, 12-O-tetradecanoylphorbol-13-acetate; COX-2, cyclooxygenase-2.

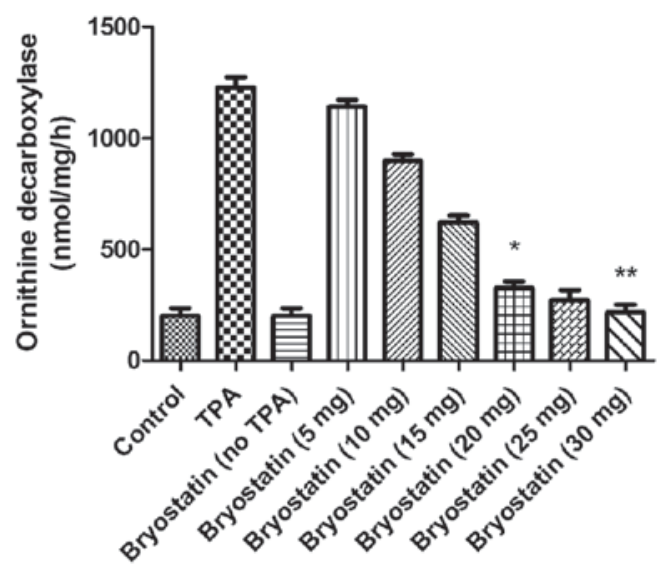

Figure 8. Bryostatin1 causes inhibition of ornithine decarboxylase activity, increased by TPA, in the mouse epidermal layer. The mice, with or without pretreatment with bryostatin 1 at $30 \mu \mathrm{M}$, were administered with a 5 -nmol concentration of TPA. Following $8 \mathrm{~h}$ of TPA administration, the epidermal layers of the mice were isolated following sacrifice of the animals to determine the ornithine decarboxylase activity. ${ }^{*} \mathrm{P}<0.05$ and ${ }^{* *} \mathrm{P}<0.01$ vs. the control group. TPA, 12-O-tetradecanoylphorbol-13-acetate.

mice compared with the control. However, when mice were treated with bryostatin 1 prior to TPA administration at a dosage of $30 \mu \mathrm{M}$, the activity of ornithine decarboxylase in the epidermal layer was significantly inhibited. At 5, 10, 15, 20, 25 and $30 \mu \mathrm{M}$ doses of bryostatin 1 , the activity level of ornithine decarboxylase was reduced to $1,150,900,630,340,290$ and 240 , respectively, compared with 1,200 in TPA group (Fig. 8).

Bryostatin 1 inhibits TPA-mediated increase in progression of tumor in mouse. Examination of the mice 3 months subsequent to the administration of TPA demonstrated the appearance of papillomas in all animals. In the mice treated with bryostatin 1 at $30-\mu \mathrm{M}$ doses prior to the administration of

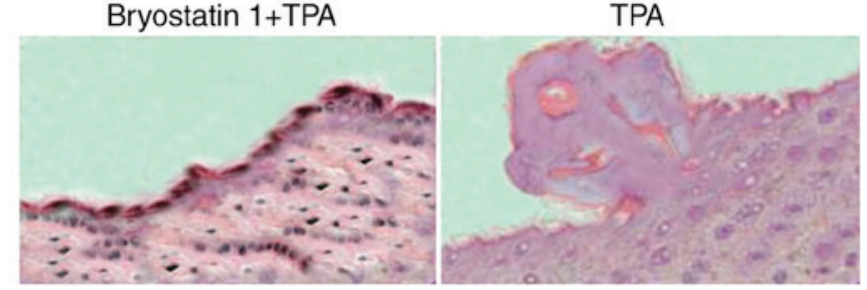

Figure 9. Bryostatin1 inhibits the TPA-mediated increase in the progression of skin tumors in mice. Tumor growth was initiated in mouse skin by treating with benzo[ $\alpha]$ pyrene at a concentration of $200 \mathrm{nmol}$. At 7 days, the mice pretreated with bryostatin 1 at $30-\mu \mathrm{M}$ doses or those without pretreatment were administered with a 5-nmol concentration of TPA. The mice were examined for 3 months to calculate the percentage of animals with tumors in the skin and the number of tumors in the skin for each animal. Magnification, x100. TPA, 12-O-tetradecanoylphorbol-13-acetate.

TPA, the appearance of the papillomas was $20 \%$ at 2 months. Determination of papilloma multiplicity revealed 5.2 papillomas on average in all the mice administered with TPA. In the mice pretreated with bryostatin 1 at $30-\mu \mathrm{M}$ doses prior to TPA administration, the mean papilloma number in each animal was observed to be 0.4 (Fig. 9).

\section{Discussion}

The present study demonstrated the effect of bryostatin 1 on the progression of tumors of the skin in TPA-induced model skin cancer. The results demonstrated that bryostatin 1 in habited the progression of skin tumor in mice by suppressing the activity of ornithine decarboxylase and reducing the level of COX-2. A previous study revealed that damage to tissues caused by the onset of inflammatory reactions is associated with the progress of carcinoma (18). The transduction of inflammatory signals leads to an aggregation of immune cells and subsequent expression of radicals at the site of inflammation, which in turn destroy cellular components, including chromatin and membranes (19). Therefore, radical species serve an important role in the development and progression of cancer. In view of theses finding, it is evident that compounds which are able to quench radicals and inhibit inflammatory reactions may be of value for the treatment of carcinoma. The present study illustrated that bryostatin 1 exhibitedanti-oxidative potential in vitro and in vivo. Bryostatin 1 inhibited the radical activity of DPPH completely at a $30-\mu \mathrm{M}$ dose in vitro. In vivo, pretreatment with bryostatin 1 prevented the formation of $\mathrm{H}_{2} \mathrm{O}_{2}$ in the pidermal layer of TPA-mediated skin tumor model mice. The expression of myeloperoxidase in 
the epidermal layer of skin tumor model mice represents the production of radicals (20). The results of the present study demonstrated that pretreatment with bryostatin 1 inhibited the expression of myeloperoxidase in TPA-treated mice. It has been reported that prostaglandin formation from arachidonic acid is catalyzed by the enzyme COX (21). It is known that COX-2 expression is enhanced by various factors, including toxic secretions from bacteria, tumor promoting agents and pro-inflammatory cytokines $(22,23)$. An increased level of COX-2 leads to the onset of inflammatory reactions and promotes tumor progression (24). Therefore, it has been proposed that diminishing the expression of COX-2 maybe of therapeutic value for the prevention of inflammation (24). The present study demonstrated that mice administered with TPA exhibited marked increased level of the protein COX-2. However, treatment of the mouse with bryostatin1 prior to TPA administration inhibited the TPA-mediated increase in the level of COX-2. Inflammation of tissues results in the promotion of ornithine decarboxylase activity, which subsequently serves an important role in the progression of skin tumors in mice (25). Ornithine decarboxylase, on activation, catalyzes the formation of polyamine in cells which promotes the development of tumors (25). The results of the present study demonstrated marked increase in the activity of ornithine decarboxylase in the TPA-treated mice. However, treatment with bryostatin 1 prior to TPA administration in habited he activity of ornithine decarboxylase in the epidermal layer. Compounds derived from plants are being evaluated for therapeutic value against various disorders, with the aim of developing novel and efficient treatment strategies (26). The results of the present study revealed that bryostatin 1 reduced the number of papillomas in each mouse in addition to the number of mice with papillomas. Therefore, bryostatin 1 exhibited the potential to act as a chemo preventive agent against skin tumor development.

In conclusion, bryostatin 1 inhibited the development and progression of tumors of the skin in mice through the prevention of inflammation-inducing processes and the quenching of radicals. Therefore, bryostatin 1 may be suggested to exert an important role in the treatment of skin tumor.

\section{References}

1. Bishop JM: Molecular themes in on cogenesis. Cell 64: 235-248, 1991.

2. Knudson AG: Hereditary predisposition to cancer. Ann NY Acad Sci 833: 58-67, 1997.

3. Boutwell RK: Some biological aspects of skin carcinogenisis. Prog Exp Tumor Res 4: 207-250, 1964.

4. Slaga TJ: Cancer: Etiology, mechanisms, and prevention - a summary. Carcinog Compr Surv 5: 243-262, 1980.

5. DiGiovanni J: Multistage carcinogenesis in mouse skin. Pharmacol Ther 54: 63-128, 1992.
6. Kim EJ, Park H, Kim J and Park JH: 3,3'-diindolylmethane suppresses 12-O-tetradecanoylphorbol-13-acetate-induced inflammation and tumor promotion in mouse skin via the downregulation of inflammatory mediators. Mol Carcinog 49: 672-683, 2010

7. Budunova IV, Perez P, Vaden VR, Spiegelman VS, Slaga TJ and Jorcano JL: Increased expression of p50-NF-kappaB and constitutive activation of NF-kappaB transcription factors during mouse skin carcinogenesis. Oncogene 18: 7423-7431, 1999.

8. Przybyszewski J, Yaktine AL, Duysen E, Blackwood D, Wang W, Au A and Birt DF: Inhibition of phorbol ester-induced AP-1-DNA binding, c-Jun protein and c-jun mRNA by dietary energy restriction is reversed by adrenalectomy in SENCAR mouse epidermis. Carcinogenesis 22: 1421-1427, 2001.

9. Walaszek Z, Hanausek M and Slaga TJ: Mechanisms of chemoprevention. Chest 125 (5 Suppl): 128-133, 2004.

10. De Flora $S$ and Ferguson LR: Overview of mechanisms of cancer chemopreventive agents. Mutat Res 591: 8-15, 2005.

11. Pettit GR, Herald CL, Doubek DL, Herald DL, Arnold E and Clardy J: Isolation and structure of bryostatin 1. J Am Chem Soc 104: 6846-6848, 1982.

12. May WS and Sensenbrenner LL: Stimulation of stem cell growth by the bryostatins. US Patent 5358711 A. Filed September 10, 1993; issued November 23, 1994.

13. Hennings H, Blumberg PM, Pettit GR, Herald CL, Shores R and Yuspa SH: Bryostatin 1, an activator of protein kinase C, inhibits tumour promotion by phorbol esters in SENCAR mouse skin. Carcinogenesis 8: 1343-1346, 1987.

14. Dale IL and Gescher A: Effects of activators of protein kinase C, including bryostatins 1 and 2 on the growth of A549 human lung carcinoma cells. Int J Cancer 43: 158-163, 1989.

15. Krafft AS, William F, Pettit GR and Lilly MB: Varied differentiation responses of human leukaemias to bryostatin 1. Cancer Res 49: 1287-1293, 1989.

16. Hornung RL, Pearson JW, Beckwith M and Longo DL: Preclinical evaluation of bryostatin1 as an anticancer agent against several murine tumour cell lines: in vitro versus in vivo activity. Cancer Res 52: 101-107, 1992

17. Morgan MD: Oxidized polyamines and the growth of human vascular endothelial cells. Prevention of cytotoxic effects by selective acetylation. Biochem J 242: 347-352, 1987.

18. Hussain SP, Hofseth LJ and Harris CC: Radical cause of cancer. Nat Rev Cancer 3: 276-285, 2003.

19. Prescott SM and Fitzpatrick FA: Cyclooxygenase-2 and carcinogenesis. Biochim Biophys Acta 1470: M69-M78, 2000.

20. Trush MA, Egner PA and Kensler TW: Myeloperoxidase as a biomarker of skin irritation and inflammation. Food Chem Toxicol 32: 143-147, 1994

21. Hamberg M and Samuelsson B: On the mechanism of the biosynthesis of prostaglandins E-1 and F-1-alpha. J Biol Chem 242: 5336-5343, 1967.

22. Gately S: The contributions of cyclooxygenase- 2 to tumor angiogenesis. Cancer Metastasis Rev 19: 19-27, 2000.

23. Marton LJ and Pegg AE: Polyamines as targets for therapeutic intervention. Annu Rev Pharmacol Toxicol 35: 55-91, 1995.

24. Chun KS, Keum YS, Han SS, Song YS, Kim SH and Surh YJ: Curcumin inhibits phorbol ester-induced expression of cyclooxygenase-2 in mouse skin through suppression of extracellular signal-regulated kinase activity and NF-kappaB activation. Carcinogenesis 24: 1515-1524, 2003.

25. Coussens LM and Werb Z: Inflammation and cancer. Nature 420: 860-867, 2002

26. Surh YJ: Molecular mechanisms of chemo preventive effects of selected dietary and medicinal phenolic substances. Mutat Res 428: 305-327, 1999. 